\title{
Design of Carbon Monoxide (CO) and Smoke Sensor, and Creation of Warning System with Fixed Telephone Call Using These Sensors
}

\author{
Abdülkadir ÇAKIR ${ }^{1 *}$, Halis SIPAHi ${ }^{1}$, Hasan TEZCAN $^{1}$, Seyit AKPANCAR ${ }^{1}$
}

\begin{abstract}
A sensor system has been designed and realized, in order to prevent considerably the carbon monoxide (CO) gas poisoning, caused by the combustion of the substances containing hydro-carbon $(\mathrm{HC})$ for heating purposes in our country. The system controls $\mathrm{CO}$ and smoke, which adversely affect human health. In the event of $\mathrm{CO}$ and smoke in the air, a fixed phone call warning system has been installed to alert the user.
\end{abstract}

For CO sensor; The ash particles which was formed as a result of chemical synthesis of polypyrrole (Ppy), iron (III) chloride and acetic acid $\left(\mathrm{CH}_{3} \mathrm{COOH}\right)$ components, was compressed into a single piece by pressing with Hydraulic Press Machine. The electrical current conductivity was measured by the electrodes immersed in this monolithic product which its surface conductivity differs according to the ratio of $\mathrm{CO}$ in the air. Thus, the measurement of $\mathrm{CO}$ in any environment was able to be performed.

For smoke sensor; A duct system was established to measure the density of smoke particles present in the atmosphere. Inside of this duct, a source of LED light, and a phototransistor system was placed in order to perceive the reflected rays emitted from this light source, by crashing to the smoke particles. And, the amount of reflected light connected to the smoke particles inside of the duct was measured. Thus, the measurement of smoke in any environment was able to be performed.

Keywords: CO sensor, Carbon monoxide sensor, Smoke sensor, Early warning system.

\section{INTRODUCTION}

In our country, hundreds of people are poisoned because of the $\mathrm{CO}$ gas, leaking from the stoves used for heating purposes in winter. Many people lose their lives every year, due to the poisoning because of fossil fuels (coal, oil, natural gas, etc.) containing hydrocarbon (HC) which are burned unconsciously (Mureşan et al., 2019; Yıldız, 2011; Yorulmaz et al., 2017).

CO gas sensor which is formed as a result of the synthesis of Ppy, iron (III) chloride, and acid components, activates the alert circuits by perceiving the level of $\mathrm{CO}$ in the air.

Such studies attract intensive attention in our country and in the world (Bui et al., 2019; Li et al., 2019; Okamoto et al., 1980). Especially, CO gas sensor design is not available in our country. With this study, extending the use of such sensors and warning systems in our country was aimed. For this purpose, giving acceleration to the domestic production by

\footnotetext{
${ }^{1}$ Isparta University of Applied Sciences, Faculty of Technology, Department of Electrical and Electronics Engineering, Isparta, Turkey.

*Corresponding author: abdulkadircakir@isparta.edu.tr

Gönderim Tarihi / Received Date : 26.07.2019

Kabul Tarihi / Accepted Date: 29.05.2020
} 
reducing the production cost, and contributing to world science, reveal the importance of this study.

\section{CO GAS}

$\mathrm{CO}$ is a poisonous gas that takes place in the smoke formed as a result of burning or incompletely burning fuels containing "carbon" in its structure such as natural gas, kerosene, gasoline, bottled gas, coal and wood. CO is a gas which is colorless, odorless, tasteless (ie difficult to feel), lighter than the air and toxic even at very low concentrations. It is usually collected in the upper parts of the rooms, in the ceiling, because it is lighter than air. Additionally, since CO gas is flammable, when it's mixture in the air is between $12-75 \%$, it is explosive. When fossil fuels with $\mathrm{HC}$, such as coal and oil, are burned with insufficient oxygen (air), CO gas is revealed (Equation 1) (Kaya, 2005; Mureşan et al., 2019).

$$
\mathrm{C} \text { (solid coal) }+1 / 2 \mathrm{O}_{2} \text { (airborne) } \rightarrow \mathrm{CO} \text { (resulting gas) }
$$

By looking at the colour of flame, it can be determined whether the combustion is complete or incomplete:

- Blue colour of flame generally refers to the full combustion,

- Orange colour of flame refers to an incomplete combustion (formation of CO gas),

- And yellow coloured flame refers to the heater never burns (Kaya, 2005).

\section{CARBON DIOXIDE $\left(\mathrm{CO}_{2}\right)$ GAS}

When there is enough oxygen $\left(\mathrm{O}_{2}\right)$ in the atmosphere, $\mathrm{CO}_{2}$ and water vapor $\left(\mathrm{H}_{2} \mathrm{O}\right)$ are released as a result of combustion (Equation 2) (Kaya, 2005).

$$
\mathrm{C} \text { (solid coal) }+\mathrm{O}_{2} \text { (airborne) } \rightarrow \mathrm{CO}_{2} \text { (resulting gas) }
$$

$\mathrm{CO}_{2}$ is a colorless, odorless, tasteless gas which is heavier than air and it is a suffocative gas. When this gas cannot be thrown out of chimney as a result of combustion and if its ratio is more than $0,5 \%$ at the same time, it poses danger to human health (Kaya, 2005).

\section{THE EFFECTS OF CO GAS ON HUMAN HEALTH}

CO gas even in very small amounts affect human health in a negative way. CO's interest in hemoglobin is 250-300 times higher than in $\mathrm{O}_{2}$. As soon as $\mathrm{CO}$ gas is inhaled, it passes into the blood directly, like $\mathrm{O}_{2}$ from the lung. The erythrocyte cells in the blood enable the red blood cells to carry $\mathrm{O}_{2}$ and $\mathrm{CO}$ gas directly gets connected to the bisphosphoglycerate bond of erythrocyte cells. Normally, the $\mathrm{O}_{2}$ gas is connected to this bond.

This reaction produces carboxyhemoglobin. When $\mathrm{CO}$ gas is connected to this bond instead of $\mathrm{O}_{2}, \mathrm{O}_{2}$ cannot be carried to surrounding body cells. Thus, $\mathrm{CO}$ poisoning occurs in the body as a result of a very serious reaction, and this poisoning leads the person directly to death. If the person suffering from $\mathrm{CO}$ poisoning is asleep, he/she will not even realize it and can't wake up from sleep again (Kaya and Ergözen, 2019). 


\section{DESIGN OF CARBON MONOXIDE (CO) AND SMOKE SENSOR, AND CREATION OF WARNING SYSTEM WITH FIXED TELEPHONE CALL USING THESE SENSORS}

The established system consists of 4 parts: Power Unit, CO Sensor, Smoke Sensor and System's Control Unit. The block diagram of the implemented system is as in figure 1.

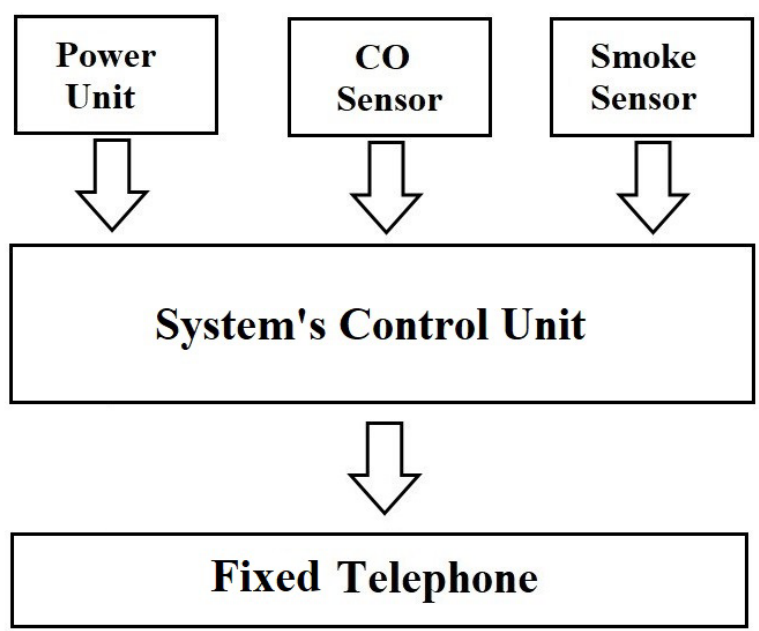

Figure 1: Block Diagram of the Implemented System.

Power requirement of Control Unit, $\mathrm{CO}$ and Smoke Sensor is met by Power Unit. The sensors data from the $\mathrm{CO}$ and Smoke sensor is received by the Control Unit and the alert information is sent to the fixed telephone by the Control Unit when the conditions determined by the user meet.

\subsection{Power Unit}

Power Unit is the section that is formed to meet the energy required for the system implemented. The circuit created in the Power Unit is as in Figure 2.

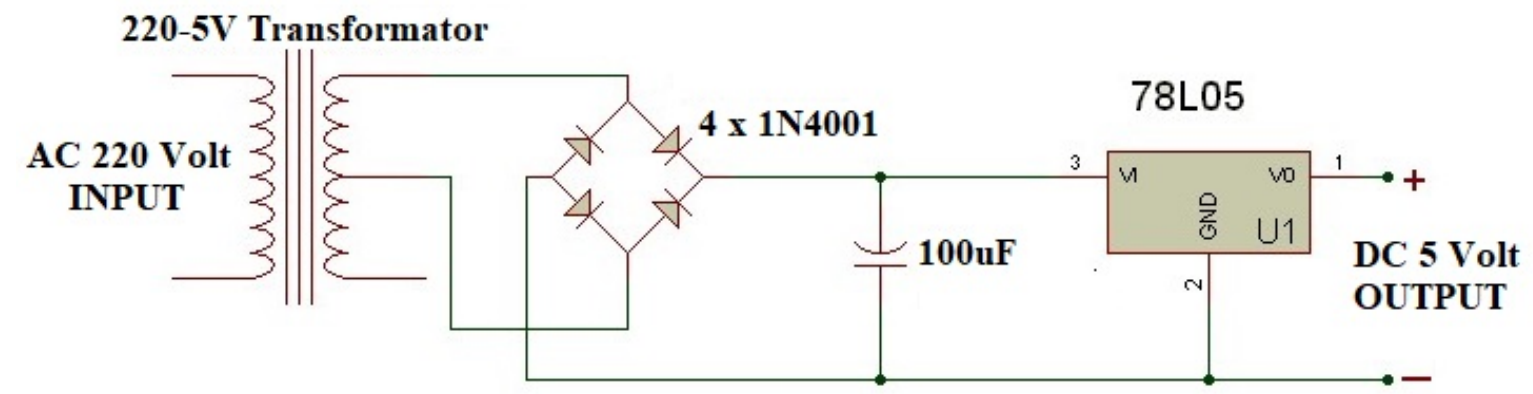

Figure 2: The Circuit of the Power Unit for the Implemented System.

With the circuit in Figure 2, AC 220 volt mains voltage is reduced to DC 5 volts and the energy requirement of the system is met.

\subsection{CO Sensor}

The CO gas sensor in this study are formed by the combination of the components Ppy, Iron (III) chloride, $\mathrm{CH}_{3} \mathrm{COOH}(100 \%$, d: $1,050 \mathrm{~g} / \mathrm{mL})$ in certain ratios as a result of various chemical syntheses. 


\subsubsection{Polypyrrole (Ppy)}

Polymers are known as the substances having a high electrical resistivity and they are used as the cover of the materials used in electrical transfer, like electrical cables. But, the metals are good electrical conductors as opposite to polymer materials. However they may not be preferred a conductive material since they are not as light and formable as polymer materials. There are many studies in the literature oriented to the production of a single conductive material that can be formed by combining different types of conductive materials (powdered iron or salt) with polymer materials in certain ratios (Aydın, 2007). As a result of these studies, it was observed that polyacetylene (an insulant material convertible into a good thin film) converted to a good conductor by increasing $10^{8}-10^{9}$ times, when it was exposed to the vapor of iodine, fluorine or chlorine. The first step, also the most important one in conductivity was taken in the year of 1979 by obtaining Ppy material by oxidizing of pyrrole material using electrochemical methods (Gürses, 2016).

Today, many conductive polymers are being prepared. In our study, Ppy was preferred, because its monomer (pyrrole) can be oxidized easily, soluble in water and it is easily available in the market since it is more preferred commercially.

There are two main methods used in the synthesis of Ppy; chemical and electrochemical. The chemical method provides an advantage in term of obtaining large amounts of product and being cheap (Coşkun, 2009). Therefore, the chemical method was used for the synthesis of Ppy in mediums $\mathrm{CH}_{3} \mathrm{COOH}$ and $\mathrm{CH}_{3} \mathrm{COOH} / \mathrm{Cu}(0)$.

Synthesis of Ppy in $\mathrm{CH} 3 \mathrm{COOH}$ medium: 10 millimoles $(0.707 \mathrm{~mL})$ of pyrrole were added to 100 milliliters of 1 mole of $\mathrm{CH}_{3} \mathrm{COOH}$ solution at $2-5^{\circ} \mathrm{C}$, then, 25 millimoles $(4.0625 \mathrm{~g})$ of iron (III) chloride $\left(\mathrm{FeCl}_{3}\right)$ solution which was dissolved dropwise in 100 milliliters of 1 mole of $\mathrm{CH} 3 \mathrm{COOH}$ solution under nitrogen atmosphere were added over it. As a result of 16 hours of polymerization, the polymer solid was obtained. Firstly it was washed in 1 mole of $\mathrm{CH}_{3} \mathrm{COOH}$ solution and then in gooch crucible with purified water under vacuum until it becomes clear. Afterward, the polymer was dried in a vacuum oven at $50^{\circ} \mathrm{C}$ for 24 hours.

Synthesis of Ppy in $\mathrm{CH}_{3} \mathrm{COOH} / \mathrm{Cu}(0)$ medium: $0.23 \mathrm{~g} \mathrm{Cu}\left(\mathrm{NO}_{3}\right)_{2} \cdot 3 \mathrm{H}_{2} \mathrm{O}$ was dissolved in 40 milliliters of water. $\mathrm{NaHB}_{4}$ was added over it till black agglomerates were seen. The obtained solution was added to 60 milliliters of 1.67 mole of $\mathrm{CH} 3 \mathrm{COOH}$ solution containing 10 millimoles $(0.707 \mathrm{~mL})$ of pyrrole, and then, 25 millimoles $(4.0625 \mathrm{~g})$ of iron (III) chloride $\left(\mathrm{FeCl}_{3}\right)$ which was dissolved dropwise in 100 milliliters of 1 mole $\mathrm{CH}_{3} \mathrm{COOH}$ solution under $2-5^{\circ} \mathrm{C}$ nitrogen atmosphere, were added over it. After 16 hours of polymerization, the resulting polymer solid was was washed first in 1 mole of $\mathrm{CH}_{3} \mathrm{COOH}$ solution and then in gooch crucible with purified water under vacuum until it becomes clear. After that, the polymer was dried in a vacuum oven at $50^{\circ} \mathrm{C}$ for 24 hours.

The material in ash form which was formed as a result of the synthesis of Ppy, iron (III) chloride and $\mathrm{CH}_{3} \mathrm{COOH}$, was placed in the steel mold in figure 3 and then became a single piece of material by applying approximately 1 ton of press using the Hydraulic Press Machine in figure 4. 


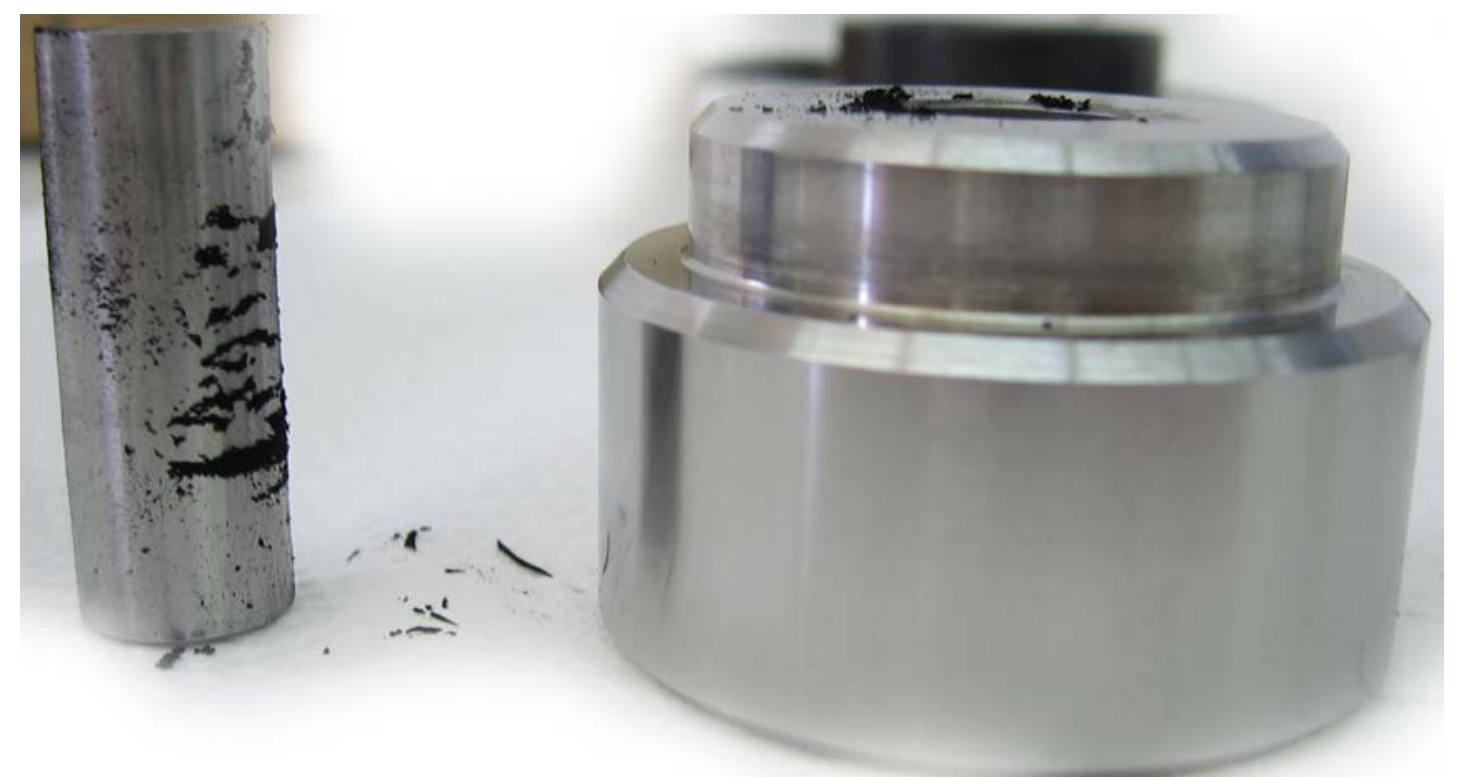

Figure 3: The Mold which Ppy was Placed in, before Applying Pressure.

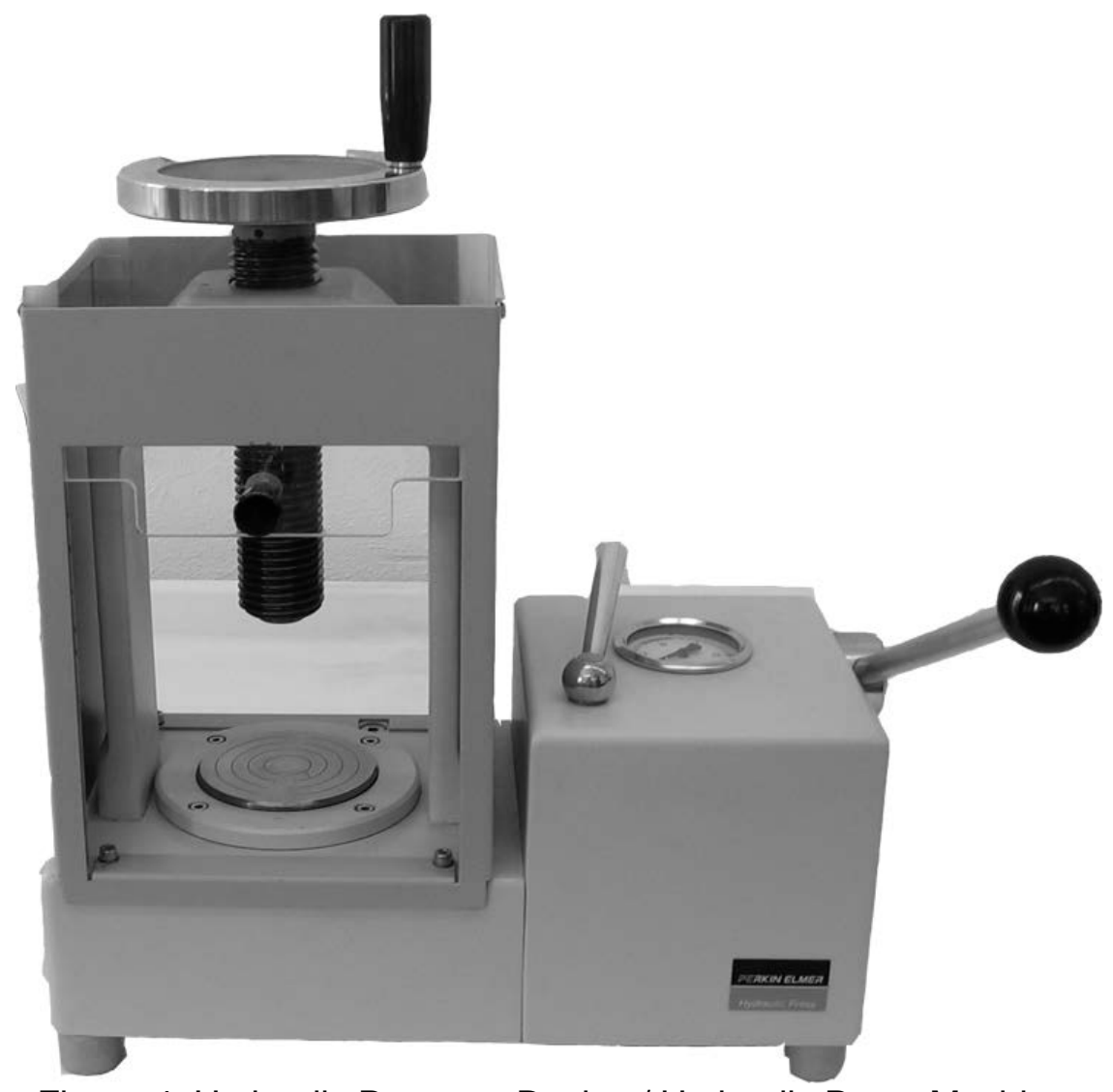

Figure 4: Hydraulic Pressure Device / Hydraulic Press Machine.

The final state of the semiconductor Ppy material which was formed for the CO gas sensor is as shown in figure 5 . 


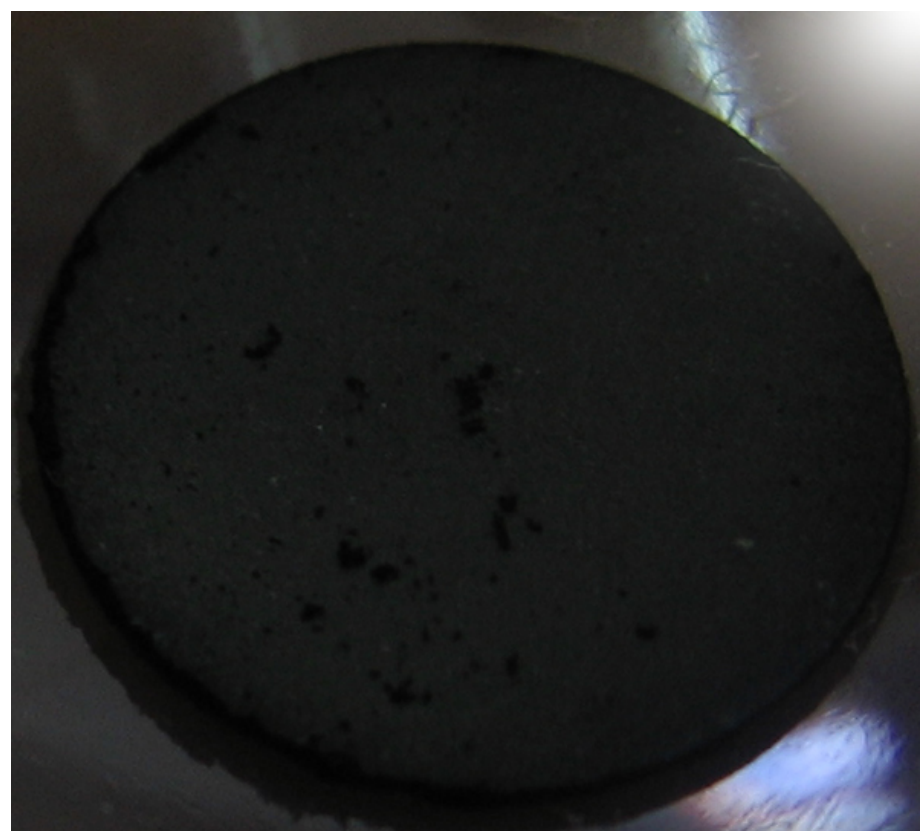

Figure 5: Final Form of Semiconductor Ppy Material.

4 electrodes were immersed in the Ppy material of Figure 5. While 2 of these electrodes were powered, voltage was read from the other 2. Thus, the resistance of the Ppy material, which varies according to the $\mathrm{CO}$ density in the environment, was measured. The control circuit of the created CO Sensor is as in Figure 6.

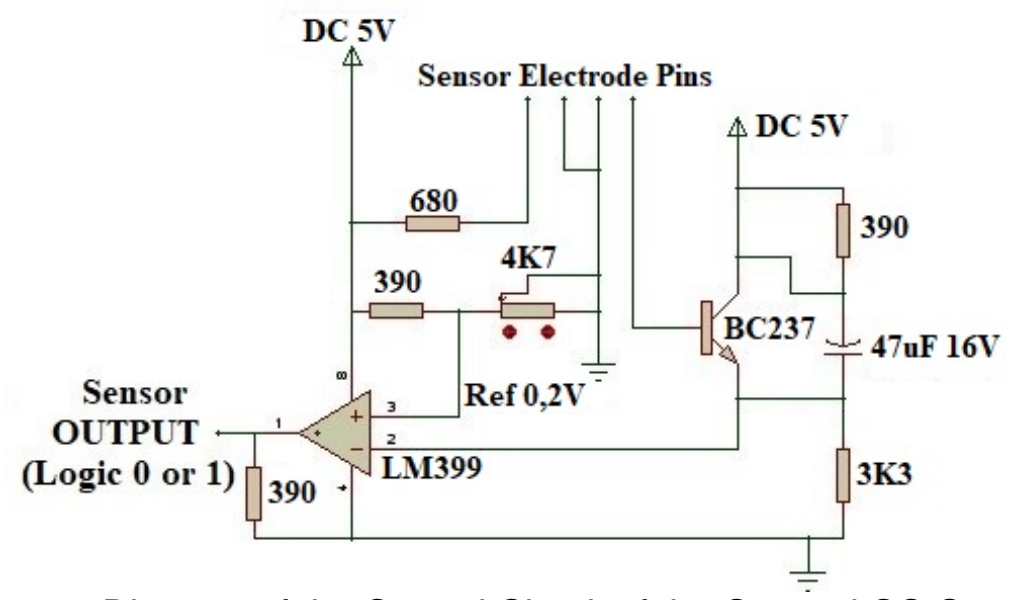

Figure 6: Diagram of the Control Circuit of the Created CO Sensor.

The resistance of the Ppy material, which varies according to the CO concentration in the environment, is compared with the reference voltage set by the potentiometer, and the OpAmp output is set to logic 0 and the control system is enabled to operate.

\subsection{Smoke Sensor}

In order to measure the amount of density of the smoke particles in the environment, the duct system in figure 7 was created. A LED light source, a phototransistor for perceiving the reflected ones of the rays emanating from this light source after crashing with the smoke particles, and a curtain bar in order to prevent the phototransistor to see the rays emitting from LED source directly, are placed in the duct (Figure 7). 


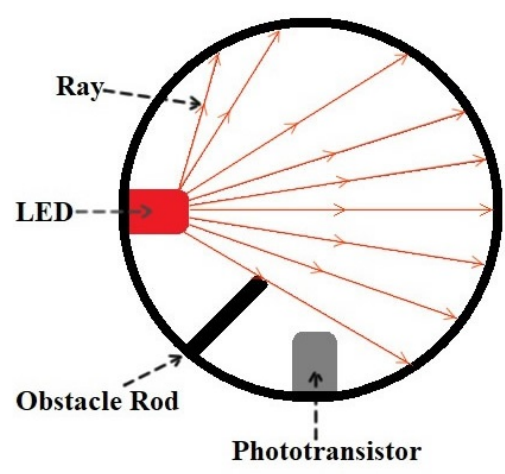

No Smoke in the Environment

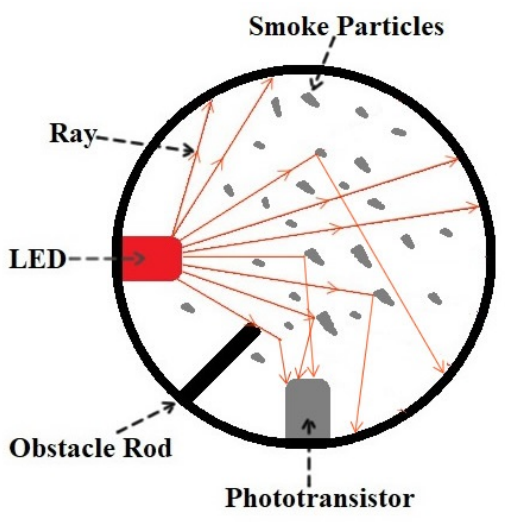

Smoke in the Environment

Figure 7: Tunnel Structure Established for Smoke Sensor.

In case of increasing the density of the smoke particles in the tunnel, more of the reflected rays emitted from LED light, fall on the phototransistor. This way, the smoke density in the media can be obtained by measuring the amount of light on phototransistor changing proportionally with the density of the smoke particles in the tunnel.

\subsubsection{Smoke Sensor Inner Structure}

The control circuit of established Smoke Sensor is as shown in figure 8.

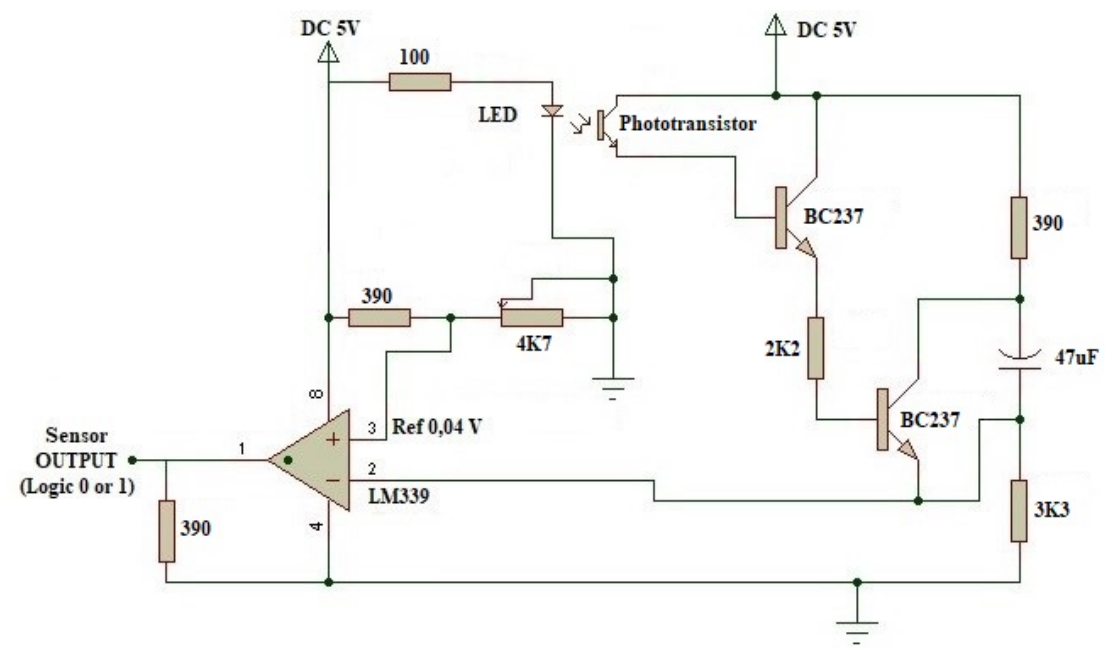

Figure 8: Diagram of the Control Circuit of Smoke Sensor.

By setting the reference value with the potentiometer in figure 8 , in case of the rays emitted from LED source comes to phototransistor in desired amount after crashing to the smoke particles, it means the output of OpAmp is reached to logic 0 . Thus, when the density of the smoke in the media reaches the set level, it becomes to the status of warning.

\subsection{System's Control Unit}

For the overall control of this system, the microcontroller in figure 9 was used. The P2.0 port of the AT89C52 microcontroller in Figure 10 are used to receive data from Smoke Sensor and P2.1 port are used to receive data from CO Sensor. Also, On/Off switches are connected to the ports P3.2 and P3.3 one by one, to activate these sensors. 
Call, End Call, M1 (Memory Button 1) and M2 (Memory Button 2) buttons of the fixed telephone used to inform the user are controlled by relays connected to the P1.0, P1.1, P1.2 and P1.3 ports of the AT89C52 microcontroller in figure 9.

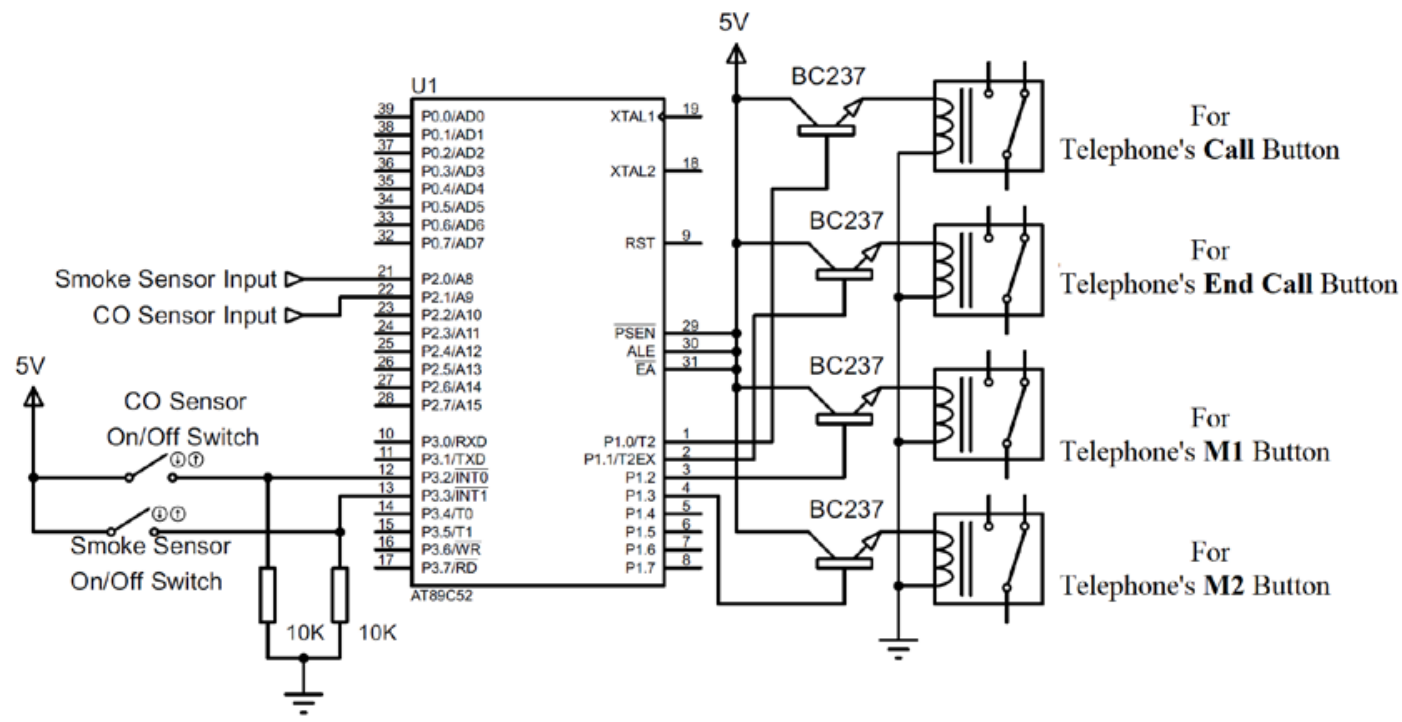

Figure 9: Overall Controller of the System.

Data from the Smoke Sensor and CO Sensor are evaluated on the AT89C52 microcontroller in Figure 9. If the density from these two sensors is high; To call the phone number previously assigned to the M1 memory button of the fixed telephone, the M1 button of the fixed telephone is activated through a relay connected to the P1.2 port of the microcontroller. Then, the Call button of the fixed telephone is activated by means of the relay connected to the P1.0 port of the microcontroller and the number registered in the M1 button is called. After this process, the same process is repeated to call the phone number assigned to the M2 button after waiting 1 minute.

In summary, if the density from the sensors is high, these 2 numbers, which are stored in the memory buttons of the fixed telephone, are called one after the other and the user is warned.

\section{CONCLUSION}

In this study, it was aimed to create a warning system to prevent the poisoning of people from $\mathrm{CO}$ gas in their living environments. Therefore, $\mathrm{CO}$ and smoke sensors were designed and implemented to prevent poisoning from $\mathrm{CO}$ and smoke. Because the $\mathrm{CO}$ gas is in a smoky form, the smoke sensor added to the warning system. A warning system was created by controlling these created sensors through the AT89C52 microcontroller.

The overview of the implemented system is as shown in figure 10. 


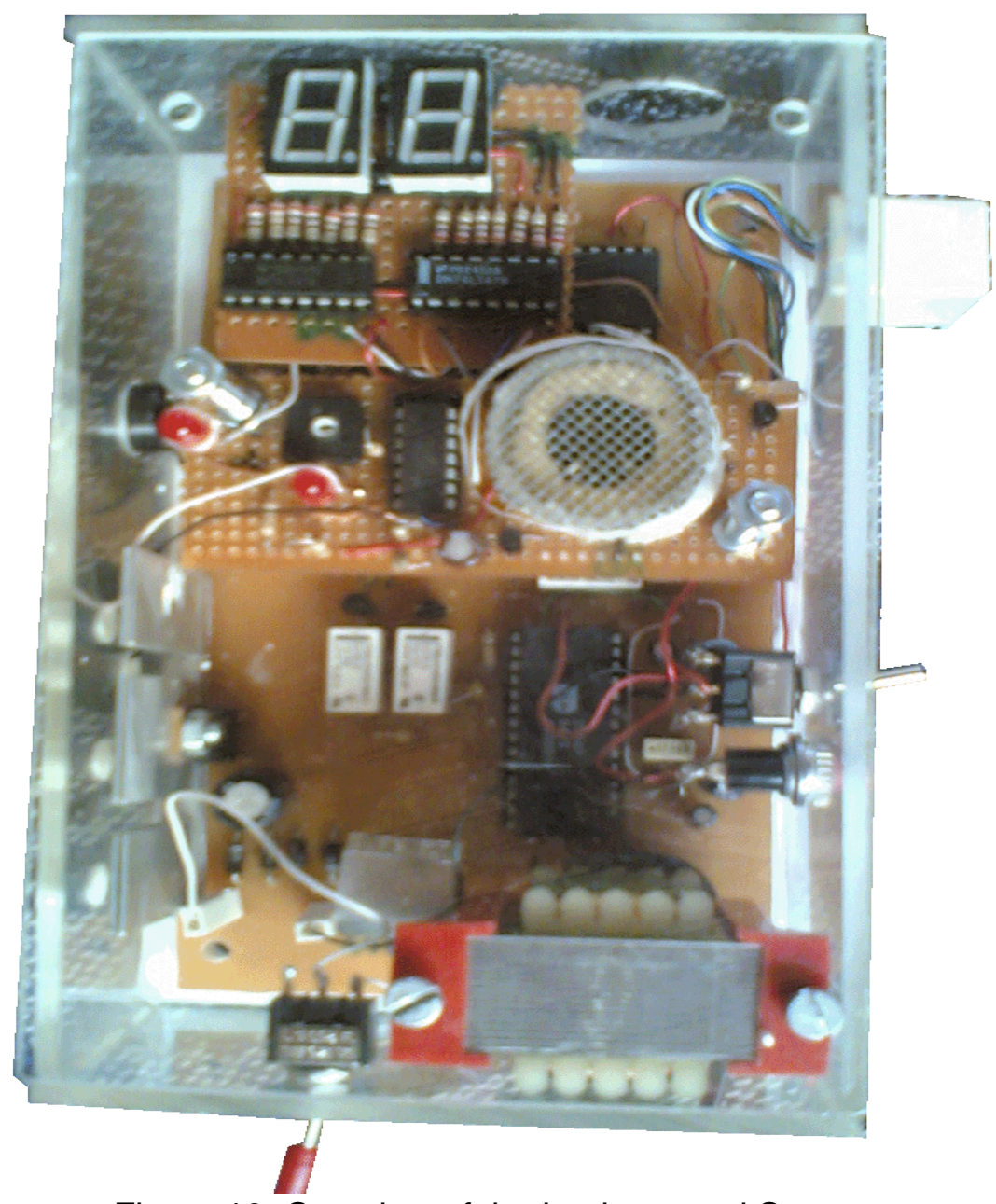

Figure 10: Overview of the Implemented System.

The CO sensor is not produced in Turkey are provided by importing.

Therefore, it is thought that this study will contribute to the literature and form the basis for future studies.

\section{REFERENCES}

Aydın, Z. (2007). Iletken Poli(Etilen Teraftalat)/Polipirol Kompozit Liflerinin Kimyasal Polimerizasyonla Hazirlanmasi ve Karakterizasyonu. (MSc thesis), Ankara Üniversitesi, Fen Bilimleri Enstitüsü, Kimya Anabilim Dalı, Ankara.

Bui, Q. C., Largeau, L., Morassi, M., Jegenyes, N., Mauguain, O., Travers, L., Lafosse, X., Dupuis, C., Harmand, J.-C., and Tchernycheva, M. (2019). GaN/Ga2O3 Core/Shell Nanowires Growth: Nanostructures for Future CO-Sensors Developments.

Coşkun, K. (2009). Kimyasal ve Elektrokimyasal Yöntemlerle Iletken Polimerlerin Sentezi ve Membran Uygulamalari. (MSc thesis), Süleyman Demirel Üniversitesi, Fen Bilimleri Enstitüsü, Kimya Anabilim Dalı, Isparta.

Gürses, A. (2016). İletken Polimerler. https://slideplayer.biz.tr/slide/9827463/

Kaya, E., and Ergözen, S. (2019). Karbonmonoksit Zehirlenmesi. Muğla Sıtkı Koçman Üniversitesi Tıp Dergisi, 6(1), 52-55. 
Kaya, M. (2005). Isınma-Isıtma Amaçlı Faaliyetlerden Kaynaklanan Zehirlenmelere Karşı Alınacak Önlemler. Retrieved January 5, 2005 https://www.termodinamik.info/isinma-isitmaamacli-faaliyetlerden-kaynaklanan-zehirlenmelere-karsi-alinacak-onlemler

Li, G., Wang, X., Yan, L., Wang, Y., Zhang, Z., and Xu, J. (2019). PdPt Bimetal Functionalized SnO2 Nanosheets: Controllable Synthesis and its Dual Selectivity for Detection of Carbon Monoxide and Methane. ACS applied materials \& interfaces.

Mureşan, C., Zăvoi, R., Dumache, R., Precup, C., Ciocan, V., Bulzan, O., Florou, C., and Enache, A. (2019). Co-morbidities in the multiple victims of the silent killer in carbon monoxide poisoning. Romanian journal of morphology and embryology= Revue roumaine de morphologie et embryologie, 60(1), 125-131.

Okamoto, H., Obayashi, H., and Kudo, T. (1980). Carbon monoxide gas sensor made of stabilized zirconia. Solid State Ionics, 1(3-4), 319-326.

Yıldız, Ş. (2011). Karbonmonoksit Zehirlenmesi ve Türkiye Verileri. IV. Ulusal Sualtı Hekimliği ve Hiperbarik Tıp Kurultayı, 34-41.

Yorulmaz, A., Akbulut, H., Yahya, İ., Aktaş, R., Emiroğlu, H. H., and Peru, H. (2017). Çocuk acil servisine zehirlenme nedeni ile başvuran olguların geriye dönük olarak değerlendirilmesi. J Pediatr Emerg Intensive Care Med, 4, 96-103. 